\title{
PARADIGMA PENDIDIKAN ISLAM MASA KINI DAN MASA DEPAN
}

\author{
Hikma H. Amidong ${ }^{1)}$, Nurysamsi Maulana Insani' ${ }^{2)}$, Andreawan ${ }^{3)}$ \\ ${ }^{1,2,3)}$ Prodi Pendidikan Bahasa dan Sastra Indonesia \\ Fakultas Sastra, Universitas Muslim Indonesia \\ Jalan Urip Sumoharjo, KM 5, Makassar \\ Email: Hikmaa54@gmail.com
}

\begin{abstract}
Abstrak: Dewasa ini pendidikan Islam berada pada posisi determinisme historik dan realisme. Dalam artian bahwa satu sisi umat Islam berada pada romantisme historis di mana mereka bangga karena pernah memiliki para pemikir-pemikir dan ilmuwanilmuwan besar dan mempunyai kontribusi yang besar pula bagi pembangunan peradaban dan ilmu pengetahuan dunia serta menjadi transmisi bagi khazanah Yunani, namun di sisi lain mereka menghadapi sebuah kenyataan, bahwa pendidikan Islam tidak berdaya dihadapkan kepada realitas masyarakat industri dan teknologi modern. Selama ini telah banyak pemikiran dan kebijakan yang diambil dalam rangka peningkatan kualitas Islam yang diharapkan mampu memberikan nuansa baru bagi pengembangan pendidikan Islam di Indonesia, dan sekaligus hendak memberikan kontribusi dalam menjabarkan makna pengembangan sistem pendidikan Islam di Indonesia, yaitu manusia yang beriman dan bertaqwa kepada Tuhan Yang Maha Esa, sebagaimana tertuang dalam tujuan pendidikan nasional (UU No. 2/1989 tentang Sistem Pendidikan Nasional).
\end{abstract}

Kata Kunci: Pendidikan, Islam Masa Kini, Islam Masa Depan

\section{PENDAHULUAN}

Pendidikan adalah sebuah proses pembentukan karakter manusia yang tidak pernah berhenti. Oleh karena itu, pendidikan merupakan sebuah proses budaya untuk membentuk karakter guna meningkatkan harkat dan martabat manusia yang berlangsung sepanjang hayat. Dari wacana inilah, jelas pendidikan merupakan landasan bagi pembentukan karakter manusia, sekaligus karakter sebuah bangsa. Bagaimana perjalanan sebuah bangsa menuju masa depannya, hal itu akan tergantung dari pendidikan yang diterima oleh "anak-anak kandung" bangsa bersangkutan. Dalam konteks inilah, pendidikan akan selalu berkembang, dan selalu dihadapkan pada perubahan zaman. Karena itu, pendidikan harus didesain mengikuti irama perubahan tersebut. Jika tidak, pendidikan akan berjalan di tempat, bahkan berjalan mundur. Bila terjadi, tunggulah kehancuran bangsa tersebut.

Bagaimana dengan pendidikan Islam? Pendidikan Islam saat ini tengah menghadapi tantangan yang tidak mudah diselesaikan.Pendidikan Islam saat ini tengan menghadapi tantangan yang tidak mudah diselesaikan. Pendidikan Islam tengah menghadapi tantangan modernisasi yang amat cepat, yang di satu sisi menciptakan era globalisasi yang menumbuhkan pemikiran-pemikiran global dan universal; tapi di pihak lain, modernisasi menciptakan kumpulankumpulan manusia ekstrim dan irasional yang membentuk sekte-sekte sebagai counter product dari globalisasi pemikiran dan budaya tadi. Alvin Toffler jauh hari telah meramalkan bahwa di era modernisasi akan muncul banyak sektesekte dan pemikiran-pemikiran ekstrim 
yang bisa mengganggu perjalanan era globalisasi tersebut.

Apa yang diprediksi Toffler kini benar-benar menjadi kenyataan. Di tengah umat manusia yang tengah menyambut era globalisasi muncul pula kelompokkelompok eksklusif yang ekstrim dan antiglobalisasi. Mereka inilah yang menyebarkan pemahaman-pemahaman sempit tentang ideologi dan agama. Mereka juga melihat manusia secara hitam putih. Munculnya pelbagai tindakan terorisme dan tindakan ekstrim lain atas nama agama, sebetulnya adalah pengejawantahan dari eksistensi kelompok-kelompok anti-globalisasi tersebut. Kelompok-kelompok semacam ini jelas menabrak kecenderungan alam dan kecenderungan manusia yang ingin terus berkembang. Mereka niscaya akan tergilas kecenderungan zaman. Namun jika dibiarkan, pemikiran kelompok semacam itu bisa menjadi virus yang akan menggerogoti bangsa. Dalam kaitan inilah, pendidikan harus mengantisipasi kecenderungan destruktif tersebut. Dan pendidikan Islam harus berjalan paling depan untuk mengatasi kondisi itu. Maklumlah sejauh ini, Islam telah menjadi "tertuduh" dari munculnya pelbagai kekerasan dan konflik ekstrim yang meresahkan dunia internasional.

Pendidikan Islam harus mewarnai segala aspek kehidupan.Islam harus muncul dalam dunia yang selama ini dianggap sekuler seperti perbankan dan kedokteran.Perbankan Islam kini sudah muncul-muncul di mana-mana. Juga pendidikan Islam yang terkait -ekonomi dan perbankan syariah- kini sudah ada di mana-mana.Bahkan Fakultas Kedokteran yang bernuansa Islam sudah berdiri di Universitas Islam Negeri (UIN) Jakarta. Apa arti semua itu? Islam dan dunia pendidikan sekuler (kedokteran) yang selama ini dianggap tabu untuk bisa bergandeng tangan, sekarang ini sudah menyatu.

Ke depan, Islam sesuai karakter ajarannya -pinjam Bella- yang modern dan universal, harus bisa menyesuaikan konsep pendidikannya yang mengikuti perkembangan zaman. Jika pendidikan Islam berhasi menyatukan "paradigm sekuler dengan paradigm spiritual dalam Islam" ke depan harus diupayakan pula agar pendidikan Islam bisa membawa masyarakat Islam ke dalam pemikiran dan perilaku yang humanis dan universal. Dunia pendidikan saat ini membutuhkan konsep dan strategi yang integral, yang bisa "mendidik" seluruh aspek kemanusian manusia dalam menghadapi tantangan arus budaya dan social yang demikian gencar lantaran perkembangan teknologi informasi yang sangat cepat.

\section{PEMBAHASAN}

Pendidikan adalah sesuatu yang universal dan berlangsung terus tak terputus dari generasi ke generasi dimana pun di dunia ini. Upaya memanusiakan manusia melalui pendidikan, itu diselenggarakan sesuai dengan pandangan hidup setiap masyarakat.Landasan dan tujuan pendidikan itu sendiri sifatnya filosofis normatif (Mansyur, 2018).

Pendidikan Islam sering diartikan secara sempit yaitu merupakan upaya melalui berbagai kegiatan pembelajaran agar ajaran Islam dapat dijadikan pedoman bagi kehidupannya sebagai bekal untuk menjadi hamba Allah yang mengabdi dan beribadat kepada-Nya.

Pada sisi lain secara luas diartikan sebagai usaha sadar untuk mengarahkan pertumbuhan dan perkembangan anak 
dengan segala potensi yang dianugerahkan Allah kepadanya agar mengemban amanat dan tanggung jawab sebagai khalifah Allah di bumi dalam pengabdiannya kepada Allah Swt.

Kedua pengertian tersebut (baik dalam arti sempit maupun arti luas) diperlakukan secara terpadu dengan maksud agar manusia mampu mengolah dan menggunakan segala kekayaan yang ada di langit dan di bumi untuk memperoleh kebahagian dan kesejahteraan di dunia serta keselamatan di akhirat kelak. Gambaran manusia yang diharapkan melalui proses pendidikan Islam yang demikian adalah seorang muslim yang beriman kepada Allah. Bertaqwa, berakhlak mulia, beramal kebaikan, menjalankan perintah Allah dengan menjauhi larangan-Nya, menguasai ilmu pengetahuan (dunia dan akhirat) dan menguasai keterampilan dan keahlian agar dapat memikul amanat dan tanggung jawab yang dibebankan kepadanya sesuai kemampuannya masing-masing.

Penerapan dan pengertian pendidikan Islam yang demikian harus diletakkan dalam konteks sosial kutural bangsa Indonesia yaitu agar serasi dan terpadu dalam rangka pendidikan nasional sesuai dengan Undang-undang No. 20 Tahun 2003 Tentang sistem Pendidikan Nasional.

\section{Paradigma Pendidikan Islam}

Paradigma adalah kumpulan tata nilai yang membentuk pola pikir seseorang sebagai titik tolak pandangannya sehingga akan membentuk citra subyektif seseorang dan akhirnya akan menentukan bagaimana seseorang menaggapi realita itu. Paradigma pendidikan terbagi atas tiga yaitu:

\section{Paradigma Holistik}

Paradigma holistik merupakan suatu filsafat pendidikan yang berangkat dari pemikiran bahwa pada dasarnya seorang individu dapat menemukan identitas, makna dan tujuan hidup melalui hubungannya dengan masyarakat, lingkungan alam, dan nilai-nilai spiritual.

Pada era tahu 1960-an pendidikan holistik sempat ditingalkan para pakarnya, namun pada tahun 1970-an mulai dikembangkan kembali sejak dilaksanakan konferensi pertama pendidikan Holistik Internasional yang diselenggarakan oleh Universitas California pada bulan Juli 1979, dengan menghadirkan thema The Mandala Society dan The National Center for the Exploration of Human Potential.

Tujuan pendidikan holistik adalah membantu mengembangkan potensi individu dalam suasana pembelajaran yang lebih menyenangkan dan menggairahkan, demoktaris dan humanis melalui pengalaman dalam berinteraksi dengan lingkungannya. Melalui pendidikan holistik, peserta didik diharapkan dapat menjadi dirinya sendiri (learning to be). Dalam arti dapat memperoleh kebebasan psikologis, mengambil keputusan yang baik, belajar melalui cara yang sesuai dengan dirinya, memperoleh kecakapan sosial, serta dapat mengembangkan karakter dan emosionalnya (Basil Bernstein).

Sembilan pilar karakter yang dikembangkan di dalam penyelenggaraan pendidikan holistik: cinta Tuhan dan segenap ciptaan-Nya, kemandirian dan tanggungjawab, kejujuran/amanah, diplomatis, hormat dan santun dermawan, suka tolong-menolong dan gotong royong/ kerjasama, percaya diri dan pekerja keras, kepemimpinan dan keadilan, baik dan rendah hati, karakter toleransi, kedamaian, 
dan kesatuan. Model pendidikan holistik menggunakan tiga metode, yaitu: knowing the good, feeling the good, dan acting the good. Knowing the good bisa mudah diajarkan sebab pengetahuan bersifat kognitif saja. feeling loving the good, yakni bagaimana merasakan dan mencintai kebajikan menjadi engine yang selalu bekerja membuat orang mau selalu berbuat sesuatu kebaikan. Orang mau melakukan perilaku kebajikan karena dia cinta dengan perilaku kebajikan itu. Acting the good berubah menjadi kebiasaan.

Setiap anak untuk tiba pada perilaku berkarakater kuat membutuhkan proses luar biasa sulit, butuh perjuangan yang tidak mudah. Namun kalau anak sudah terbiasa berbuat baik, sekali dia berbuat tidak baik sudah tidak enak. Timbul budaya malu dalam dirinya jika melakukan perbuatan buruk. Termasuk menyontek pada saat ulangan.

\section{Paradigma Humanistik}

Paradigma pendidikan humanistik memandang manusia sebagai "manusia", yakni makhluk ciptaan Tuhan dengan fitrah-fitrah tertentu. Sebagai makhluk hidup ia harus melangsungkan, mempertahankan, dan mengembangkan hidup. Sebagai makhluk batas (antara hewan dan malaikat), ia memiliki sifat-sifat kehewanan (nafsu-nafsu rendah) dan sifatsifat kemalaikatan (budi luhur), sebagai makhluk dilematik ia selalu dihadapkan pada pilihan-pilihan dalam hidupnya; sebagai makhluk moral, ia bergulat dengan nilai-nilai; sebagai makhluk pribadi, ia memiliki kekuatan konstruktif dan destruktif; sebagai makhluk sosial, ia memiliki hak-hak sosial; sebagai hamba Tuhan, ia harus menunaikan kewajibankewajiban keagamaannya.
Ada beberapa nilai dan sikap dasar manusia yang ingin diwujudkan melalui pendidikan humanistik yaitu: manusia yang menghargai dirinya sendiri sebagai manusia, manusia yang menghargai manusia lain seperti halnya dia menghargai dirinya sendiri, manusia memahami dan melaksanakan kewajiban dan hak-haknya sebagai manusia, manusia memanfaatkan seluruh potensi dirinya sesuai dengan kemampuan yang dimilikinya, dan manusia menyadari adanya kekuatan akhir yang mengatur seluruh hidup manusia.

Selain itu, menjadi manusia bukan sekedar dapat makan untuk hidup, tetapi lebih dari itu menjadi manusia berarti memiliki tanggung jawab terhadap dirinya sendiri, keluarga, masyarakat, bangsa dan negaranya. Pendidikan humanis adalah proses pendidikan yang membangun karakter kemanusiaan dalam diri manusia, yang menghargai harkat dan martabat manusia lain, yang tidak terlepas dari moral hidup bersama atau moral sosial.

Muara pendidikan yang manusiawi adalah mewujudkan pendidikan yang bermakna, yakni suatu sistem pendidikan yang menekankan pada watak (karakter) atau moral dalam sistem nilai dan aktualisasi diri, pada peserta didik. Dan ini berarti meninggalkan sistem pendidikan yang menekankan pada pemupukan pengetahuan atau "knowledge deposit" (paradigma pendidikan intelektualis). Pendidikan humanis ini memiliki beberapa ciri, yaitu: memandang pendidikan sebagai sebuah sistem organik, bukan mekanik. Tidak memisahkan antara teori dan praksis. Memperlakukan peserta didik bukan sebagai bahan mentah, melainkan sebagai individu yang memiliki bakat dan minat tertentu. 


\section{Paradigma Pluralisme}

Paradigma plural memandang manusia sebagai sosok yang independent, bebas dan memiliki otoritas serta otonomi untuk melakukan pemaknaan dan menafsirkan realitas sosial yang ada disekitarnya. Tindakan manusia sulit diprediksi, karena adanya kesadaran yang berbeda antar manusia. Manusia sebagai aktor sosial menafsirkan dunia empiris mereka sendiri secara bebas dan berbeda satu dengan lain. Dengan demikian, aspek kualitatif lebih dikedepankan dibandingkan aspek kuantitatif.

Immanuel Kant merupakan filosof utama yang dijadikan basis paradigma pluralis. Menurut Kant (dalam Supriadi, 2018), manusia pada hakekatnya adalah makhluk yang suka berteman sekaligus juga berkompetisi, namun manusia tetap senang dengan harmoni. Manusia bertindak atas kesadaran subyektif, dan memiliki kebebasan menafsirkan realitas di lingkungannya secara aktif. Sementara, menurut J. Rousseau, masyarakat adalah sebuah kontrak sosial. Ada struktur internal yang membentuk kesadaran manusia, dimana kontrak sosial merupakan sebuah mekanisme untuk melakukan kontrol.

Sejalan dengan konsep manusia Kant, Rousseau mengembangkan teori kontrak sosial. Dalam teori ini, terbentuknya negara (masyarakat politik) karena anggota masyarakat mengadakan kontrak sosial untuk membentuk negara. Sumber kewenangan di sini adalah masyarakat itu sendiri.

Meski pada prinsipnya manusia sama, namun alam dan lingkungan lain telah menciptakan ketidaksamaan. Muncul hak-hak istimewa yang dimiliki beberapa orang tertentu. Mereka lebih kaya, lebih dihormati, dan lebih berkuasa. Untuk menghindari ketidaktoleranan dan kelabilan, masyarakat mengadakan kontrak sosial. Ini merupakan kehendak bebas dari semua untuk memantapkan keadilan dan pencapaian moralitas terbaik. Melalui kontrak sosial individu akan dapat mempertahankan dirinya agar tetap jadi manusia merdeka.

Dalam pradigma pluralis, manusia merupakan makhluk dengan ciri dualisme yaitu sebagai makhluk sosial (sociable) sekaligus berkesadaran secara individu (self assetive). Bukannya eksternal tidak mampu menekan manusia, namun perilaku manusia adalah makhluk yang intentional sekaligus voluntary. Kebebasan lebih dimaknai sebagai hal yang personal dan individual, bukan sebagai hal yang kolektif.

Dalam memandang masyarakat, paradigma ini melihat bahwa realitas sosial merupakan dunia yang subjektif, yang dibentuk karena ada ide dan makna yang saling didistribusikan. Karena makna yang dibagi tidak sealu sama, maka yang terbentuk adalah masyarakat heterogen. Resiprositas dalam arti luas merupakan basis relasi dalam masyarakat, dimana tiap orang berorientasi pada orang lain.

Masalah pendidikan merupakan masalah yang sangat penting dan tidak bisa dipisahkan dari seluruh rangkaian kehidupan manusia. Kebanyakan manusia memandang pendidikan sebagai sebuah kegiatan mulia yang akan mengarahkan manusia pada nilai-nilai yang memanusiakan. Pandangan bahwa pendidikan sebagai kegiatan yang sangat sakral dan mulia telah lama diyakini oleh manusia. Namun di dekade 70-an dua orang tokoh pendidikan, yaitu Paulo Freire dan Ivan Illich melontarkan kritik yang sangat mendasar tentang asumsi tersebut. Mereka menyadarkan banyak orang bahwa 
pendidikan yang selama ini disakralkan dan diyakini mengandung nilai-nilai kebajikan tersebut ternyata mengandung penindasan.

\section{Pendidikan Islam Masa Kini}

Terkait dengan ketertinggalan pendidikan Islam ini, menurut Muhaimin (dalam Al Jawahir, 2012) dikarenakan oleh terjadinya penyempitan terhadap pemahaman pendidikan Islam yang hanya berkisar pada aspek kehidupan ukhrawi yang terpisah dengan kehidupan duniawi, atau aspek kehidupan rohani yang terpisah dengan kehidupan jasmani.

Jika melihat pendapat Muhaimin ini, maka akan tampak adanya pembedaan dan pemisahan antara yang dianggap agama dan bukan agama, yang sakral dengan yang profan antara dunia dan akhirat. Cara pandang yang memisahkan antara yang satu dengan yang lain ini disebut sebagai cara pandang dikotomik. Adanya simtom dikotomik inilah yang menurut Abdurrahman Mas'ud sebagai penyebab ketertinggalan pendidikan Islam. Hingga kini pendidikan Islam masih memisahkan antar akal dan wahyu, serta fakir dan zikir. Hal ini menyebabkan adanya ketidakseimbangan paradigmatik, yaitu kurang berkembangnya konsep humanisme religius dalam dunia pendidikan Islam, karena pendidikan Islam lebih berorientasi pada konsep 'abdullah (manusia sebagai hamba), ketimbang sebagai konsep khalifatullah (manusia sebagai khalifah Allah).

Selain itu orientasi pendidikan Islam yang timpang tindih melahirkan masalah-masalah besar dalam dunia pendidikan, dari persoalan filosofis, hingga persoalan metodologis. Di samping itu, pendidikan Islam menghadapi masalah serius berkaitan dengan perubahan masyarakat yang terus menerus semakin cepat, lebih-lebih perkembangan ilmu pengetahuan yang hampir-hampir tidak memeperdulikan lagi sistem suatu agama.

Kondisi sekarang ini, pendidikan Islam berada pada posisi determinisme historik dan realisme. Dalam artian bahwa, satu sisi umat Islam berada pada romantisme historis di mana mereka bangga karena pernah memiliki para pemikir-pemikir dan ilmuwan-ilmuwan besar dan mempunyai kontribusi yang besar pula bagi pembangunan peradaban dan ilmu pengetahuan dunia serta menjadi transmisi bagi khazanah Yunani, namun di sisi lain mereka menghadapi sebuah kenyataan, bahwa pendidikan Islam tidak berdaya dihadapkan kepada realitas masyarakat industri dan teknologi modern.

Hal ini pun didukung dengan pandangan sebagian umat Islam yang kurang meminati ilmu-ilmu umum dan bahkan sampai pada tingkat "diharamkan". Hal ini berdampak pada pembelajaran dalam sistem pendidikan Islam yang masih berkutat apa yang oleh Muhammad Abed al-Jabiri, pemikir asal Maroko, sebagai epistemologi bayani, atau dalam bahasa Amin Abdullah disebut dengan hadharah an-nashsh (budaya agama yang sematamata mengacu pada teks), di mana pendidikan hanya bergelut dengan setumpuk teks-teks keagamaan yang sebagian besar berbicara tentang permasalahan fikih semata.

Terjadinya pemilahan-pemilahan antara ilmu umum dan ilmu agama inilah yang membawa umat Islam kepada keterbelakangan dan kemunduran peradaban, lantaran karena ilmu-ilmu umum dianggap sesuatu yang berada di luar Islam dan berasal dari non-Islam atau the other, bahkan seringkali ditentangkan 
antara agama dan ilmu (dalam hal ini sains).Agama dianggap tidak ada kaitannya dengan ilmu, begitu juga ilmu dianggap tidak memeperdulikan agama. Begitulah gambaran praktik kependidikan dan aktivitas keilmuan di tanah air sekarang ini dengan berbagai dampak negataif yang ditimbulkan dan dirasakan oleh masyarakat.

Sistem pendidikan Islam yang ada hanya mengajarkan ilmu-ilmu agama saja. Di sisi lain, generasi muslimyang menempuh pendidikan di luar sisitem pendidikan Islam hanya mendapatkan porsi kecil dalam hal pendidikan Islam atau bahkan sama sekali tidak mendapatkan ilmu-ilmu keIslaman.

Dari berbagai persoalan pendidikan Islam di atas dapat ditarik benang merah problematika pendidikan Islam yaitu: Pertama, masih adanya problem konseptual-teoritis atau filosofis yang kemudian berdampak pada persoalan operasional praktis. Kedua, persoalan konseptual-teoritis ini ditandai dengan adanya paradigma dikotomi dalam dunia pendidikan Islam antara agama dan bukan agama, wahyu dan akal serta dunia dan akhirat. Ketiga, kurangnya respon pendidikan Islam terhadap realitas sosial sehingga peserta didik jauh dari lingkungan sosio-kultural mereka. Pada saat mereka lulus dari lembaga pendidikan Islam mereka akan mengalami socialshock. Keempat, penanganan terhadap masalah ini hanya sepotong-potong, tidak integral dan komprehensif.

\section{Solusi Problematika Pendidikan Islam}

Mencermati kenyatan tersebut, maka mau tidak mau persoalan konsep dualisme-dikotomik pendidikan harus segera ditumbangkan dan dituntaskan, baik pada tingkatan filosofis-paradigmatik maupun teknis departementel. Pemikiran filosofis menjadi sangat penting, karena pemikiran ini nanti akan memeberikan suatu pandangan dunia yang menjadi landasan idiologis dan moral bagi pendidikan.

Pemisahan antar ilmu dan agama hendaknya segera dihentikan dan menjadi sebuah upaya penyatuan keduannya dalam satu sistem pendidikan integralistik. Namun persoalan integrasi ilmu dan agama dalam satu sistem pendidikan ini bukanlah suatu persoalan yang mudah, melainkan harus atas dasar pemikiran filosofis yang kuat, sehingga tidak terkesan hanya sekedar tambal sulam.

Langkah awal yang harus dilakukan dalam mengadakan perubahan pendidikan adalah merumuskan "kerangka dasar filosofis pendidikan" yang sesuai dengan ajaran Islam, kemudian mengembangkan secara "empiris prinsipprinsip" yang mendasari terlaksananya dalam konteks lingkungan (sosio dan kultural) Filsafat Integralisme (hikmah wahdatiyah) adalah bagian dari filsafat Islam yang menjadi alternatif dari pandangan holistik yang berkembang pada era postmodern di kalangan masyarakat barat.

Inti dari pandangan hikmah wahdatiyah ini adalah bahwa yang mutlak dan yang nisbi merupakan satu kesatuan yang berjenjang, bukan sesuatu yang terputus sebagaimana pandangan ortodoksi Islam. Pandangan Armahedi Mahzar, pencetus filsafat integralisme ini, tentang ilmu juga atas dasar asumsi di atas, sehingga dia tidak membedakan antara ilmu agama dan ilmu umum, ilmu Tuhan dan ilmu skular, ilmu dunia dan ilmu akhirat. Dari pandangan dia tentang kesatuan tersebut juga akan berimplikasi pula pada pemikiran Armahedi pada 
permasalahan yang lain, termasuk juga pendidikan Islam.

Bagi Armahedi, pendidikan Islam haruslah menjadi satu kesatuan yang utuh atau integral. Baginya, manusia-manuisa saat ini merupakan produk dari pemikiran Barat Modern yang mengalami suatu kepincangan, karena merupakan suatu perkembangan yang parsial. Peradaban Islam adalah contoh lain. Keduanya dapat ditolong dengan membelokkan arah perkembangannya ke arah perkembangan yang evolusioner yang lebih menyeluruh dan seimbang.Hanya ada beberpa sisi saja dari kehidupan manusia yang dikembangkan.Begitu juga halnya dengan masyarakat yang ada, pada hakikatnya adalah cerminan dari satu sistem pendidikan yang ada saat itu.

Masyarakat saat ini adalah masyarakat materialis yang dapat dibina dengan menggunakan suatu mesin raksasa yang bernama teknostrutur.Di sini ada satu link yang hilang, yaitu spiritualisme. Dengan demikian, pendidikan sebagai produksi sistem ini haruslah mengembangkan seluruh aspek dari manusia dan masyarakat sesuai dengan fitrah Islam, yaitu tauhid.

Pandangan filosofis inilah yang menjadikan pentingnya kajian terhadap pemikiran Armahedi Mahzar tentang sistem pendidikan Islam integratif, karena permasalahan pendidikan sebenarnya terletak pada dua aspek, filosofis dan praktis.Persoalan filosofis ini yang menjadi landasan pada ranah praktis pendidikan. Ketika ranah filosofis telah terbangun kokoh, maka ranah praktis akan berjalan secara sistematis. Dengan demikian, filsafat integralisme atau hikmah wahdatiyah nantinya akan menjadi landasan idiologis dalam pengembangan sistem pendidikan integratif.

\section{Masa Depan Pendidikan Islam}

Pendidikan adalah sebuah proses pembentukan karakter manusia yang tidak pernah berhenti. Oleh Karena itu, pendidikan merupakan sebuah proses budaya untuk membentuk karakter guna meningkatkan harkat dan martabat manusia yang berlangsung sepanjang hayat. Dari wacana inilah, jelas pendidikan merupakan landasan bagi pembentukan karakter manusia, sekaligus karakter sebuah bangsa. Bagaimana perjalanan sebuah bangsa menuju masa depannya, hal itu akan tergantung dari pendidikan yang diterima oleh "anak-anak kandung" bangsa bersangkutan. Dalam konteks inilah, pendidikan akan selalu berkembang, dan selalu dihadapkan pada perubahan zaman. Karena itu, pendidikan harus didesain mengikuti irama perubahan tersebut. Jika tidak, pendidikan akan berjalan di tempat, bahkan berjalan mundur. Bila terjadi, tunggulah kehancuran bangsa tersebut.

Bagaimana dengan pendidikan Islam? Pendidikan Islam saat ini tengah menghadapi tantangan yang tidak mudah diselesaikan.Pendidikan Islam saat ini tengan menghadapi tantangan yang tidak mudah diselesaikan. Pendidikan Islam tenga menghadapi tantangan modernisasi yang amat cepat, yang di satu sisi menciptakan era globalisasi yang menumbuhkan pemikiran-pemikiran global dan universal; tapi di pihak lain, modernisasi menciptakan kumpulankumpulan manusia ekstrim dan irasional yang membentuk sekte-sekte sebagai counter product dari globalisasi pemikiran dan budaya tadi. Alvin Toffler jauh hari telah meramalkan bahwa di era modernisasi akan muncul banyak sektesekte dan pemikiran-pemikiran ekstrim yang bisa mengganggu perjalanan era globalisasi tersebut. 
Apa yang diprediksi Toffler kini benar-benar menjadi kenyataan. Di tengah umat manusia yang tengah menyambut era globalisasi muncul pula kelompokkelompok eksklusif yang ekstrim dan antiglobalisasi.Mereka inilah yang menyebarkan pemahaman-pemahaman sempit tentang ideologi dan agama.Mereka juga melihat manusia secara hitam putih.

Munculnya pelbagai tindakan terorisme dan tindakan ekstrim lain atas nama agama, sebetulnya adalah pengejawantahan dari eksistensi kelompok anti-globalisasi tersebut. Kelompokkelompok semacam ini jelas menabrak kecenderungan alam dan kecenderungan manusia yang ingin terus berkembang. Mereka niscaya akan tergilas kecenderungan zaman. Namun jika dibiarkan, pemikiran kelompok semacam itu bisa menjadi virus yang akanmenggerogoti bangsa.

Dalam kaitan inilah, pendidikan harus mengantisipasi kecenderungan destruktif tersebut. Dan pendidikan Islam harus berjalan paling depan untuk mengatasi kondisi itu. Maklumlah sejauh ini, Islam telah menjadi "tertuduh" dari munculnya pelbagai kekerasan dan konflik ekstrim yang meresahkan dunia internasional.

Masyarakat modern dewasa ini ditandai dengan munculnya era pascaindustri (postindustrial society) seperti dikatakan Daniel Bell, atau masyarakat informasi (information society) sebagai tahapan ketiga dari perkembangan peradaban seperti dikatakan oleh Alvin Tofler, tak pelak lagi telah menjadikan kehidupan manusia secara teknologis memperoleh banyak kemudahan. Tapi masyarakat modern juga menjumpai banyak paradox dalam kehidupannya.
Dalam bidang revolusi informasi, misalnya, sebagaimana dikemukakan Donald Michael, juga terjadi ironi besar.Semakin banyak informasi dan semakin banyak pengetahuan, mastinya manusia makin besar kemampuannya melakukan pengendalian umum.Tapi yang terjadi justru sebaliknya; makin banyak informasi makin banyak yang tidak terkendali. Karena itu dengan ekstrim Ziauddin Sardar (dalam Pranowo M. Bambang, 2009: 26), menyatakan bahwa abad informasi ternyata sama sekali bukan rahmat. di masyarakat Barat, ia telah menimbulkan sejumlah besar persoalan, yang tidak ada perpecahannya kecuali cara pemecahan yang tumpul (Malik Fajar, 1995).

Di Indonesia, kondisi serupa mulai menggejala. melimpahnya informasi membuat masyarakat makin bingung dalam mencari arah kehidupannya. Di antara mereka ada yang berhasil mencari arah yang benar, tapi tidak sedikit yang terjerumus ke dalam situasi yang ambigu, baik ambigu dalam menentukan mana yang baik dan buruk, maupun ambigu dalam menentukan pilihan-pilihan yang tepat untuk menyonsong era post industri tersebut.

Untuk melihat bagaimana Indonesia membangun masa depan pendidikan Islamnya, mungkinkita perlu melihat perkembangan sejarah pendidikan Islam di tanah air kita. Ketika Indonesia masih dijajah Belanda, pilihan yang dianggap tepat oleh masyarakat untuk pendidikan Islam saat itu adalah menjauhi apa-apa yang berbau Belanda.Dalam perkembangannya, yang berbau Belanda itu identik dengan yang berbau Barat. Maka, pendidikan yang berbau Barat pun dijauhi. Oleh sebab itu, di kalangan umat 
yang berkembang adalah pendidikan model padepokan dan pesantren.

Pesantren sendiri sebetulnya model pendidikan padepokan ala agama Hindu.Santri berasal dari kata cantri yang artinya murid-murid yang mempelajari agama Hindu.Benar, kaum santri, dengan kepatuhan tinggi padsa kiainya yang kharismatik, adalah pejuang-pejuang tangguh yang anti-belanda.Peperangan antara santri dan tentara Belanda terjadi di mana-mana.Kaum santri dan pesantrennya menjadi penangkal pengaruh Belanda di masyarakat tradisional Indonesia yang notabene merupakan masyarakat mayoritas.

Lalu bagaimana ke depan? Pendidikan Islam harus mewarnai segala aspek kehidupan.Islam harus muncul dalam dunia yang selama ini dianggap sekuler seperti perbankan dan kedokteran.Perbankan Islam kini sudah muncul-muncul di mana-mana. Juga pendidikan Islam yang terkait -ekonomi dan perbankan syariah- kini sudah ada di mana-mana. Bahkan Fakultas Kedokteran yang bernuansa Islam sudah berdiri di Universitas Islam Negeri (UIN) Jakarta. Apa arti semua itu? Islam dan dunia pendidikan sekuler (kedokteran) yang selama ini dianggap tabu untuk bisa bergandeng tangan, sekarang ini sudah menyatu.

Ke depan, Islam sesuai karakter ajarannya - pinjam Bella - yang modern dan universa, harus bisa menyesuaikan konsep pendidikannya yang mengikuti perkembangan zaman. Jika pendidikan Islam berhasi menyatukan "paradigm sekuler dengan paradigm spiritual dalam Islam" ke depan harus diupayakan pula agar pendidikan Islambisa membawa masyarakat Islam ked lam pemikiran dan perilaku yang humanis dan universal.
Dunia pendidikan saat ini membutuhkan konsep dan strategi yang integral, yang bisa "mendidik" seluruh aspek kemanusian manusia dalam menghadapi tantangan arus budaya dan social yang demikian gencar lantaran perkembangan teknologi informasi yang sangat cepat. Ajaran Islam yang sarat dengan nilai-nilai luhur bisa menjadi landasan moral yang sangat strategis dalam mengembangkan pendidikan Islam di tengah arus informasi global yang kurang memperhatikan nilainilai kemanusian yang dasariah tersebut. Itu semua adalah tantangan yang harus dijawab oleh umat Islam, agar Islam benar-benar menjadi rahmatan lil'alamin .

\section{PENUTUP}

Agama Islam datang ke Indonesia dibawa oleh para pedagang muslim. Sambil berdagang menyiarkan agama Islam kepada orang-orang yang mengelilinya yaitu mereka yang membeli barang-barang dagangannya. Begitulah setiap ada kesempatan mereka memberikan pendidikan dan ajaran agama Islam.

Pendidikan Islam dapat diartikan sebagai usaha sadar untuk mengarahkan pertumbuhan dan perkembangan anak dengan segala potensi yang dianugerahkan Allah kepadanya agar mengemban amanat dan tanggung jawab sebagai khalifah Allah di bumi dalam pengabdiannya kepada Allah Swt.

Kondisi sekarang ini, pendidikan Islam berada pada posisi determinisme historik dan realisme. Dalam artian bahwa, satu sisi umat Islam berada pada romantisme historis di mana mereka bangga karena pernah memiliki para pemikir-pemikir dan ilmuwan-ilmuwan besar dan mempunyai kontribusi yang 
besar pula bagi pembangunan peradaban dan ilmu pengetahuan dunia serta menjadi transmisi bagi khazanah Yunani, namun di sisi lain mereka menghadapi sebuah kenyataan, bahwa pendidikan Islam tidak berdaya dihadapkan kepada realitas masyarakat industri dan teknologi modern.
Pendidikan Islam harus mewarnai segala aspek kehidupan.Islam harus munculdalam dunia yang selama ini dianggap sekuler, seperti perbankan dan kedokteran,

\section{DAFTAR PUSTAKA}

Jawahir Al. 2012. Problematika Pendidikan Islam Masa Kini dan Akan Datang. www. Academia.edu/29690478/_Problematika_Pendidikan_Islam_Masa_Kini_dan_Masa_ Akan_Datang.

Mansyur, Umar. (2018). Sistem Pendidikan Nasional: Mencerdaskan atau Menindas? https://doi.org/10.31227/osf.io/kfvb5

Muhaimin. 2004. Paradigma Pendidikan Islam. Bandung: PT Remaja Rosda Karya.

Pranowo M. Bambang. 2009. Mereka Bicara Pendidikan: Sebuah Bunga Rampai. Jakarta: PT. Rajagrafindo Persada.

Supriadi. 2018. Paradigma Pendidikan Islam di Indonesia. (Online), www.teoribagus.com. Teja. 2012. Paradigma Pendidikan Islam. (Online), www.teja.blogspot.com Zuhairini, dkk. Sistem dan Isi Pendidikan Islam. 2000. Jakarta: PT. Bumi Aksara. 